\title{
Glyphosate: To Use or Not to Use
}

ISSN: 2637-7659

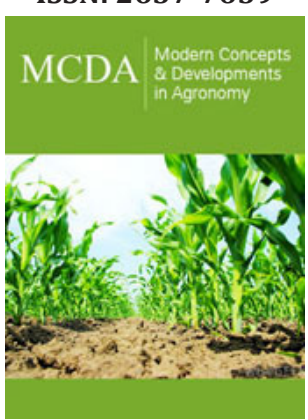

*Corresponding author: Ricardo Labrada, Ex-FAO Technical Officer, Plant Protection Service, Rome, Italy

Submission: 眥 June 03, 2021

Published: 隔June 14, 2021

Volume 8 - Issue 5

How to cite this article: Ricardo Labrada. Glyphosate: To Use or Not to Use. Mod Concep Dev Agrono. 8(5). MCDA. 000697. 2021. DOI: 10.31031/MCDA.2021.08.000697

Copyright@ Ricardo Labrada. This article is distributed under the terms of the Creative Commons Attribution 4.0 International License, which permits unrestricted use and redistribution provided that the original author and source are credited.

\section{Ricardo Labrada*}

Ex-FAO Technical Officer, Plant Protection Service, Rome, Italy

\section{Opinion}

The herbicide historically most used in agriculture worldwide has been glyphosate, which is useful to control a vast number of annual and perennial weeds in arable areas and in other non-crop areas. Its application dates back more than 40 years. At that moment, it was understood that this molecule was of low toxicity, and it did not cause problems to humans and the environment.

Glyphosate use in the US has reached 1.6 billion kilograms of active ingredient since 1974, out of a total amount of 8.6 billion kilograms globally, $56 \%$ of the amount consumed globally currently corresponds to its application in genetically modified herbicide-resistant crops (HRC) [1].

The use of glyphosate has helped farmers to protect their crops from the negative effects of weeds, but due to its continuous application, it has also generated problems, particularly in HRCs due to the appearance of resistant weed biotypes. According to Heap [2] thirty-eight weed species have now evolved resistance to glyphosate, distributed across 37 countries and in 34 different crops and six non-crop situations. Farmers not having appropriate knowledge on herbicide resistance, wrongly repeat glyphosate application in fields where selection of resistant biotypes is already taking place.

Increased use of glyphosate has also caused the presence of its residues on the soil and in groundwater, which constitutes a risk to the diversity due to greater exposure to the herbicide of humans and animals. The accumulation of residues in soil and water can also leave residues in the obtained crop production. Residues in these cases can be of glyphosate and its metabolite aminomethylphosphonic acid (AMPA), which has been detected in air [3], soil [4] and water [5]. Battaglin et al. [6] found residues of metabolite AMPA widely in surface and groundwater, in precipitations and soils in US.

Various publications report adverse effects of glyphosate on human health, which is due to its high and continuous use globally. There is evidence of negative effects on kidney and liver as well as increased chronic degeneration due to its continuous use [7]. Toxicity has also seen by the presence of endocrine disruptors in human cells [8].

The main producer of this herbicide has paid large sums of money as compensation for damages caused to plaintiffs in the US [9], which indicates that the harmful effects are real and not fictitious. Obviously, the society, the press and politicians in several countries alarmed by this situation suggest banning the use of glyphosate, something reasonable if there were other options available.

Weeding in gardens and small agricultural areas is not a problem. Various tools as draw hoe, rotary hoe, stirrup hoe, warren hoe and wheel hoe are available and feasible for use in small areas, but when the issue is to control weeds in large growing areas, it becomes troublesome. Whenever a chemical weed control measure is banned, the farmer does not 
demand money, but options to replace the method used in order to maintain productivity and obtain the expected economic benefits. Unfortunately, there is not a viable option to replace the use of this herbicide in the short term, especially in resistant crops associated with its use.

Different recommendations can be given, and it remains to see if the farmer welcome them. Any alternative measure must be feasible to implement in terms of cost and effectiveness. If it involves a high degree of complexity, the farmer will surely reject it.

Weeds are wrongly considered pests of secondary importance in many parts of the world, particularly in the less developed countries. In developed economies, weed control relies heavily on herbicide use, while in large crop areas of developing one's chemical control is also largely applied. In less important crops of developing countries hand weeding prevails. It clearly seems that weed control is a simple task, either to use glyphosate or to hand weed. Research funds for weed control are mostly coming from the pesticide-producing companies, but little or none from the public sector for the agricultural research centers, particularly in developing world. Even IPM promoters not often include the weed subject in their programs.

The current situation requires, on the one hand, the development of an awareness campaign among farmers of the need to reduce the use of glyphosate due to the current problems of accumulation of herbicide residues and its main metabolite. They should also learn of the consequences of these residues in the human and animal health. On the other hand, investment is required in weed management research looking for integrated environmentally friendly control measures that may help reduce the current use of this herbicide. For the time being, the talk should be reduction; its ban could come gradually with new developments derived from research that governments should sponsor. A sudden herbicide ban can create problems in weed management and even reduce farmer productivity if viable alternatives are not available to replace the use of glyphosate.

\section{References}

1. Battaglin WA, Meyer MT, Kuivila KM, Dietze JE (2014) Glyphosate and its degradation product AMPA occur frequently and widely in U.S. soils, surface water, groundwater, and precipitation. J Am Water Resour Assoc 50(2): 275-290.

2. Benbrook CM (2016) Trends in glyphosate herbicide use in the United States and globally. Environ Sci Eur 28(1): 3.

3. Borggaard OK, Gimsing AL (2008) Fate of glyphosate in soil and the possibility of leaching to ground and surface waters: a review. Pest Manag Sci 64(4): 441-456.

4. Chang F, Simcik MF, Capel PD (2011) Occurrence and fate of the herbicide glyphosate and its degradate aminomethylphosphonic acid in the atmosphere. Environ Toxicol Chem 30(3): 548-555.

5. Coupe RH, Kalkhoff SJ, Capel PD, Gregoire C (2012) Fate and transport of glyphosate and aminomethylphosphonic acid in surface waters of agricultural basins. Pest Manag Sci 68(1): 16-30.

6. DW (2020) Bayer acuerda indemnizar a demandantes en EE. UU. por caso de glifosato. DW.com.

7. Gasnier C, Dumont C, Benachour N, Clair E, Chagnon MC, et al. (2009) Glyphosate-based herbicides are toxic and endocrine disruptors in human cell lines. Toxicology 262(3): 184-191.

8. Heap I, Duke S (2017) Overview of glyphosate-resistant weeds worldwide. Pest Management Sci 74(5): 1040-1049.

9. Séralini GE, Clair E, Mesnage R, Defarge N, Malatesta M, et al. (2014) Republished study: long-term toxicity of a Roundup herbicide and a Roundup-tolerant genetically modified maize. Environ Sci Eur 26(1): 14. 